\title{
TATA LAKSANA SAR MINOR UNTUK MENGURANGI REKURENSI DAN KEPARAHAN (Laporan kasus)
}

\author{
Endah Ayu Tri Wulandari* Titiek Setyawati** \\ * PPDGS Ilmu Penyakit Mulut \\ ** Staf Pengajar Departemen Ilmu Penyakit Mulut \\ Bagian Ilmu Penyakit Mulut, Fakultas Kedokteran Gigi, Universitas Indonesia \\ Jl. Salemba Raya no. 4, Jakarta 10430. Telp. 2303257
}

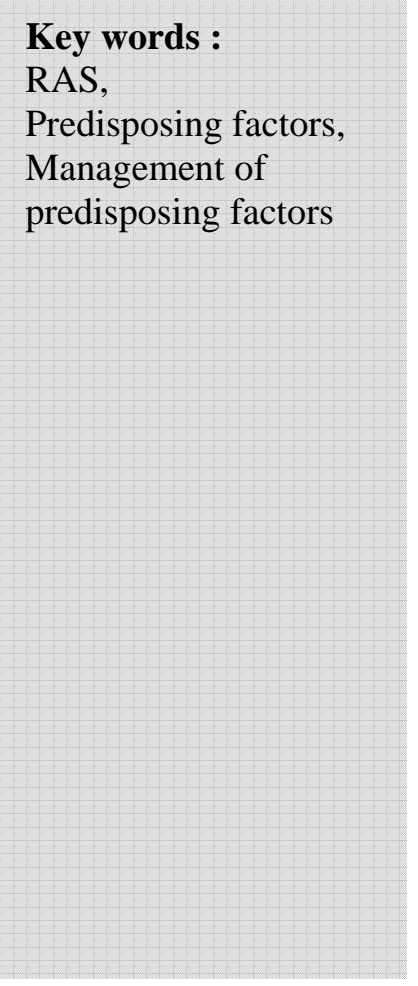

\begin{abstract}
Recurrent aphthous stomatitis (RAS) is an inflammatory condition of oral mucosa and is very common that occur in $20 \%$ of population, in which $80 \%$ of all cases are minor type. Etiology remains unknown but there are factors that can precipitate the attack, known as predisposing factors, which are haematinic deficiency, food hypersensitivity, bacterial or viral infection, hormonal changes, psychological stress, drugs and local trauma. Management of minor RAS are symptomatic and also discovering all predisposing factors which may play role in order to give the appropriate treatments to all predisposing factors. The appropriate treatment for all predisposing factors is to prevent recurrency or reduce the severity of RAS.This paper presents 2 cases of minor RAS which have bacterial infection from poor oral hygiene; local trauma from radices, irritating tooth cusp and rough surface of calculus; haematinic deficiency; physical / psychological stress and food hypersensitivity, as predisposing factors. The management of those cases are scaling, grinding irritating cusp, giving advice of proper and healthy diet including vitamin supplementation, finding any stress factor and also overcome it. We concluded that finding and eliminating predisposing factors can reduce recurrency and severity of RAS.
\end{abstract}




\section{Pendahuluan}

Stomatitis aftosa rekuren (SAR) merupakan suatu kondisi peradangan mukosa rongga mulut dengan karakteristik ulserasi ulang kambuh dan masa bebas ulkus selama beberapa hari hingga minggu ${ }^{1,2,3,4,5,6}$. SAR merupakan suatu kondisi yang sangat umum dengan prevalensi sebesar 20\% dari populasi ${ }^{2,3,6,7,8,9,10}$, dan prevalensi pada kelompok anak-anak sebesar 5-10\% ${ }^{1}$. Etiologi SAR hingga saat ini masih tidak diketahui

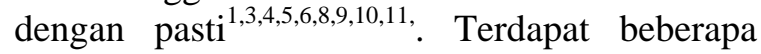
faktor yang dikatakan berperan dalam pemunculan SAR, yaitu genetik, defisiensi hematinik, hipersensitivitas terhadap makanan, infeksi bakteri dan virus, perubahan hormonal, stress

psikologik, obat obatan dan trauma lokal ${ }^{1,2,3}$, $5,6,8,9,11,12,13,14$. Pemunculan SAR mencapai puncak pada dekade kedua ${ }^{3}$. Berdasarkan jenis kelamin, SAR cenderung lebih banyak ditemukan pada wanita ${ }^{8}$.

SAR memiliki 3 bentuk umum berdasarkan klasifikasi Stanley (1972) ${ }^{3}$, yaitu SAR minor dengan 1-5 ulkus tiap episode pada mukosa tidak berkeratin tanpa menimbulkan jaringan parut, SAR mayor dengan 1-3 ulkus tiap episode pada mukosa berkeratin dan tidak berkeratin yang meninggalkan jaringan parut. Bentuk terakhir adalah SAR herpetiformis dengan 20-100 ulkus tiap episode pada mukosa tidak berkeratin yang meninggalkan jaringan parut jika ulkus-ulkus menyatu 2,3,4,5,6,8,11,12,

Tata laksana SAR berupa identifikasi dan koreksi faktor-faktor predisposisi ${ }^{5}$ Pada umumnya pasien SAR tidak memerlukan terapi karena sifat penyakitnya yang ringan ${ }^{3}$. Beberapa orang melakukan perawatan dengan menjaga kebersihan rongga mulut, menggunakan pasta gigi tanpa sodium lauryl sulfate yang bersifat iritatif, mencegah trauma lokal serta terapi paliatif untuk mengatasi rasa sakit ${ }^{3,5}$. Terapi SAR memiliki tujuan menghilangkan rasa sakit sehingga memungkinkan asupan makanan yang adekuat, mengurangi infeksi sekunder, memicu penyembuhan ulkus sehingga mengurangi durasi dan mencegah rekurensi ${ }^{2,3}$.

\section{Laporan kasus}

Pasien 1 seorang wanita berusia 41 tahun, suku Jawa, berat badan $46 \mathrm{Kg}$ dengan tinggi badan $156 \mathrm{~cm}$, bekerja di bagian farmasi Rumah Sakit Cipto Mangunkusumo (RSCM). Pasien konsul dari poli Penyakit Dalam RSCM dengan diagnosa kerja stomatitis multiple berulang dan caries dentis. Pada kunjungan ini pasien membawa hasil pemeriksaan darah perifer lengkap (DPL) dengan hasil LED $30 \mathrm{~mm}, \mathrm{Hb}$ 11,9 g/dL, Ht 36,6\%, eritrosit 4,16 juta/ul, MCV 88 fl, MCH 28,6 pg, MCHC 32,5 g/dL, leukosit 7000/ul dan trombosit 273000/ul. Pemeriksaan ekstra oral tidak ditemukan kelainan. Pemeriksaan intra oral ditemukan oral hygiene buruk, gigi anterior rahang bawah berjejal, 48 karies mencapai pulpa vital, 14 dan 17 karies dentin, beberapa ulkus dangkal putih dengan halo eritem berukuran 1-5 mm menyebar pada mukosa labial, bukal, lateral lidah dan palatum lunak (gambar 1 a, 1b, 1c, 1d, 1e). Diagnosa yang ditegakkan adalah SAR minor. Dilakukan pemberian dental health education (DHE) dan multivitamin, serta direncanakan pembersihan karang gigi, perawatan saluran akar, penambalan dan pembuatan gigi tiruan.

Pada kunjungan 1 minggu kemudian terlihat perbaikan, hanya ditemukan beberapa ulkus yang sudah menyembuh (gambar 1f, 1g, 1h). Dilakukan pemberian multivitamin dan obat kumur yang mengandung chlorhexidine gluconate $0,2 \%$ serta pengasahan tonjol-tonjol gigi yang tajam. Empat bulan kemudian pasien datang kembali dan ditemukan lebih dari 13 buah ulkus dangkal putih dengan halo eritem, diameter 1-3 mm pada mukosa bukal, labial, palatum keras dan lunak, dan lateral lidah yang hilang timbul tanpa henti selama 3 minggu terakhir (gambar 1i, 1j, 1k, 1l, 1m, 1n). Pasien menyangkal adanya stress psikologik dan hanya mengaku kelelahan. Dicurigai keterlibatan infeksi virus herpes simpleks (HSV) karena adanya ulkus pada palatum keras. Dilakukan pemberian DHE dan obat kumur yang mengandung povidon iodine $1 \%$. Dilakukan pemeriksaan DPL dan anti HSV 1 dan 2 dengan hasil LED 25 mm, Hb 11,6 g/dL, Ht 35,2\%, eritrosit 4,03 juta/ul, MCV 87,4 fl, MCH 28,8 
pg, MCHC 33 g/dl, trombosit 323000/ul, leukosit 7500/ul, anti HSV-1 IgG 0,2 (-), anti HSV-1 IgM 0,2 (-), anti HSV-2 IgG 1,1 (+), anti HSV-2 IgM 0,2 (-), hasil negatif bila $<0,9$ dan positif bila $>0,9$. Stress psikologik diduga berperan dalam memburuknya kondisi pasien sehingga dilakukan pengisian kuesioner Hamilton Rating Scale for Anxiety (HRS-A) secara tersamar karena pasien menolak mengisi HRS-A, dengan hasil adanya kecemasan ringan. Dilakukan konseling untuk membantu pasien mengatasi masalah pribadinya. Selain itu diberikan imunomodulator dan multivitamin. Pada kunjungan 1 bulan kemudian terlihat adanya 3 buah ulkus dangkal putih dengan halo eritem berdiameter 2-3 mm pada lateral lidah serta ulkus yang sudah menyembuh berupa daerah kemerahan pada mukosa bukal dan labial (gambar 1o, 1p, 1q, 1r, 1s). Dianjurkan untuk meneruskan konsumsi imunomodulator dan multivitamin. Pasien 2 seorang wanita berusia 43 tahun, suku jawa, berat badan $41 \mathrm{Kg}$, tinggi badan $160 \mathrm{~cm}$ dan bekerja sebagai pedagang keliling. Pasien konsul dari poli Kulit dan Kelamin RSCM dengan diagnosa kerja stomatitis aftosa berulang. Pada pemeriksaan klinis ekstra oral tidak ditemukan kelainan. Pemeriksaan intra oral ditemukan oral hygiene buruk, 6 sisa akar, 3 gigi dengan karies dentin, beberapa ulkus dangkal putih dengan halo eritem berdiameter 2-5 mm pada mukosa bukal, labial, dan lateral lidah (gambar 2a, 2b, 2c, 2d, 2e). Diagnosa yang ditegakkan adalah SAR minor. Dilakukan pemberian DHE, tetrasiklin kumur dan multivitamin. Direncanakan pemeriksaan DPL, pembersihan karang gigi, pencabutan, penambalan dan pembuatan gigi tiruan. Hasil pemeriksaan DPL adalah LED 40 $\mathrm{mm}, \mathrm{Hb}$ 10,8 g/dL, Ht 32,1 \%, eritrosit 4,24 juta/ul, MCV 75,7 fl, MCH 25,4 pg, MCHC 33,6 g/dL, leukosit 4650/ul dan trombosit 257000/ul.

Pada kunjungan 1 minggu kemudian terlihat ulkus-ulkus sudah menyembuh (gambar 2f, 2g, 2h, 2i). Dilakukan pemberian multivitamin serta merujuk pasien ke poli Kebidanan, akan tetapi pada saat itu hanya dilakukan pemeriksaan status ginekologis dan tidak dilakukan pemeriksaan hormonal. Pada kunjungan 4 bulan kemudian pasien mengeluhkan sariawan yang muncul tanpa henti selama 1 bulan terakhir. Pada pemeriksaan klinis ditemukan beberapa ulkus dangkal putih dengan halo eritem berdiameter 1-2 mm pada mukosa labial dan bukal (gambar 2j, 2k, 2l, $2 \mathrm{~m})$. Pasien mengakui adanya kelelahan dan stress psikologik, sehingga dilakukan pengisian kuesioner HRS-A dengan hasil adanya kecemasan ringan. Dilakukan pemberian multiv itamin, imunomodulator, serta direncanakan pembersihan karang gigi, pencabutan, penambalan dan pembuatan gigi tiruan. Pasien tidak datang kembali untuk kontrol, tetapi berdasarkan anamnesa melalui telepon 2 bulan kemudian diketahui bahwa sariawan muncul 1 kali dalam 2 bulan.

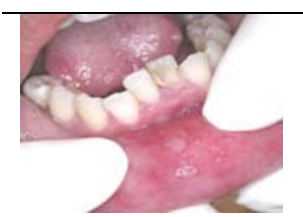

$1 \mathrm{a}$

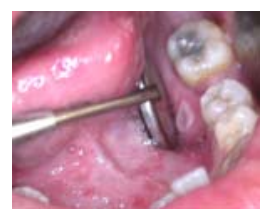

$1 \mathrm{e}$

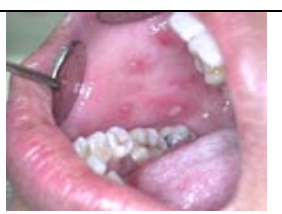

$1 \mathrm{~b}$

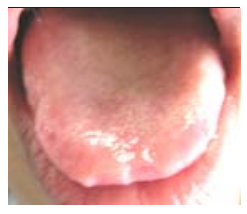

1f

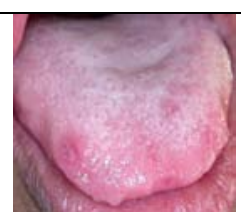

$1 c$

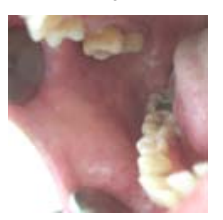

$1 g$

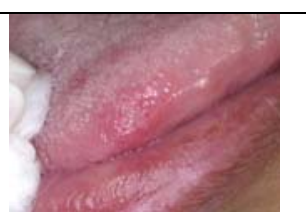

$1 d$

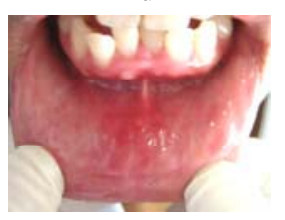

$1 \mathrm{~h}$

Gambar 1 


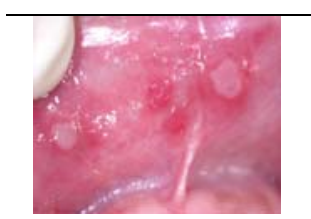

1i

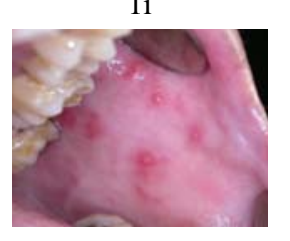

$1 \mathrm{~m}$

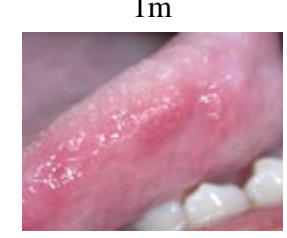

$1 \mathrm{q}$

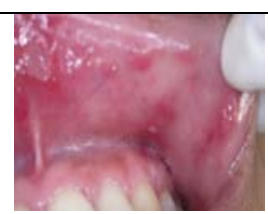

$1 \mathrm{j}$

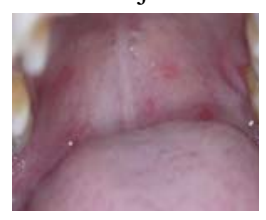

$1 n$

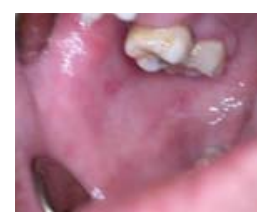

1r

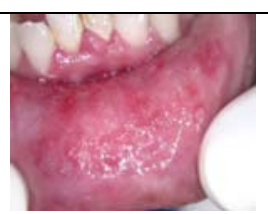

$1 \mathrm{k}$

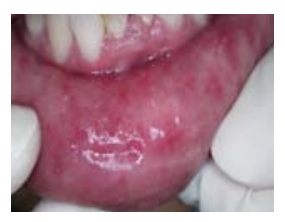

10

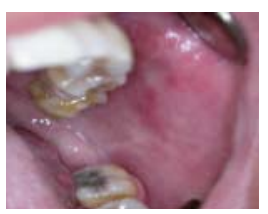

1s

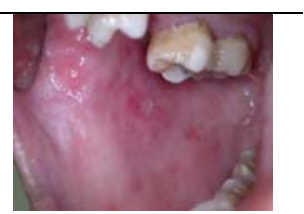

11

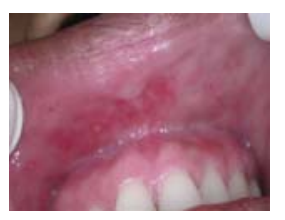

$1 \mathrm{p}$

\section{Pembahasan}

Pada kasus 1, lesi SAR pertama kali muncul pada usia 31 tahun. Hal ini sesuai dengan karakteristik SAR minor, yaitu pemunculan pertama kali pada dekade $2-3^{3}$. Sariawan muncul tanpa didahului demam atau malaise, serta tidak didahului oleh lenting. Hal ini penting untuk membedakan apakah sariawan yang diderita merupakan lesi SAR atau lesi infeksi virus, karena lesi sariawan pada infeksi virus diawali bentuk lenting dengan didahuluidemam atau malaise.

Ditemukan adanya 2 orang anggota keluarga sedarah (anggota keluarga dengan kakek dan nenek yang sama dengan pasien) dengan keluhan sariawan hilang timbul. Hal ini menandakan keterlibatan faktor genetik. Hal ini sesuai dengan literatur yang menyatakan bahwa faktor genetik menjadi faktor predisposisi pada $40 \%$ kasus $\mathrm{SAR}^{2,3}$.

Ditemukan adanya asupan gizi yang kurang baik, yaitu pasien makan 2 kali sehari, jarang makan sayur, dan sering mengganti makanan utama dengan gorengan. Berdasarkan hasil pemeriksaan di poli Penyakit Dalam, tidak ditemukan adanya gangguan pada sistem pencernaan. Hasil pemeriksaan DPL memperlihatkan penurunan kadar $\mathrm{Hb}$ dan $\mathrm{Ht}$ yang menandakan pasien menderita anemia normositik normokromik. Hal ini dapat terjadi akibat adanya malnutrisi.

Terdapat kecurigaan adanya stress psikologis karena adanya perbedaan antara data status pernikahan yang tertulis pada dokumen medis dengan keterangan yang diberikan pasien, namun pasien selalu menyangkal adanya stress psikologis.

Pemeriksaan klinis intra oral dilakukan untuk menegakkan diagnosa sesuai panduan yang diberikan oleh Natah SS, $\mathrm{dkk}^{3}$. Empat kriteria mayor yang terpenuhi adalah beberapa buah ulkus dangkal berbentuk lonjong atau bulat berdiameter tidak lebih dari $1 \mathrm{~cm}$ dengan tepi regular dikelilingi halo eritem tanpa didahului lenting, dasar ulkus kuning-kelabu, rekurensi lebih dari 3 kali dalam 3 tahun terakhir dan tidak pernah pada lokasi yang sama, adanya rasa sakit yang dieksaserbasi oleh pergerakan pada daerah berulkus, serta semua ulkus sembuh spontan tanpa meninggalkan jaringan parut. Selain itu terpenuhi 7 kriteria minor, yaitu : adanya 2 orang anggota keluarga sedarah yang juga mengalami keluhan sariawan hilang timbul, awal muncul sebelum usia 40 tahun, lokasi ulkus berpindah-pindah tetapi pada mukosa yang tidak berkeratin, durasi setiap pemunculan sekitar 7 hari, pola rekurensi tidak 
teratur, adanya defisiensi hematinik, pasien tidak merokok.

Eliminasi faktor-faktor predisposisi yang dilakukan adalah mengurangi jumlah koloni bakteri dalam rongga mulut untuk mencegah infeksi sekunder serta mempercepat penyembuhan. Hal ini dilakukan dengan meningkatkan kebersihan rongga mulut melalui tindakan DHE, pemberian obat kumur antiseptik yang mengandung chlorhexidine gluconate $0,2 \%$, pembersihan karang gigi dan pencabutan gigi yang tidak dapat dirawat lagi, serta menghilangkan trauma lokal dalam rongga mulut. Koreksi defisiensi hematinik dilakukan dengan anjuran perubahan pola makan agar asupan gizi tercukupi dan pemberian suplementasi multivitamin.

Dikunjungan berikutnya, terlihat adanya perbaikan. Rekurensi masih terjadi dengan jarak antar pemunculan 7-8 hari, tetapi dengan jumlah dan keparahan yang berkurang. Walaupun terjadi perbaikan, hasil belum memuaskan. Hal ini karena sulitnya pasien merubah pola makan menjadi lebih sehat dan pasien menolak untuk menggunakan makanan tambahan. Kecurigaan adanya keterlibatan faktor stres psikologik pada pasien ini masih belum dapat disingkirkan.

Kondisi kasus 1 kemudian memburuk dengan seluruh mukosa mulut dipenuhi ulkus baru, ulkus yang sudah mulai sembuh dan bekas ulkus berupa area kemerahan. Hal ini terjadi selama 3 minggu tanpa henti, dan berdasarkan anamnesa hal ini terjadi akibat adanya kelelahan. Melihat gambaran bekas ulkus, timbul kecurigaan adanya lesi SAR bercampur antara SAR minor dan SAR herpetiformis, dengan diagnosa banding stomatitis herpetika.

Dilakukan re-evaluasi terhadap faktorfaktor predisposisi yang sebelumnya memang sudah terdeteksi. Dilakukan pemeriksaan anti HSV 1 dan 2, karena dugaan keterlibatan infeksi virus Herpes simpleks, namun dugaan tersebut tidak terbukti. Melihat tidak sepadannya faktor predisposisi yang sudah terdeteksi dengan keparahan lesi SAR, maka memperkuat dugaan keterlibatan faktor stres psikologik pada pasien ini. Dilakukan pendekatan personal agar pasien mengakui adanya persoalan pribadi yang menjadi beban pikirannya. Dianjurkan untuk melakukan eliminasi faktor-faktor predisposisi seperti pada kunjungan sebelumnya.

Dilakukan penilaian kecemasan menggunakan HRS-A untuk mengetahui tingkat kecemasan pasien. Pasien menolak untuk dinilai kecemasannya, sehingga kemudian terjadi penyangkalan pada saat dilakukan penilaian secara tersamar. Kemungkinan hal tersebut mempengaruhi hasil yaitu tingkat kecemasan pasien berada pada kecemasan ringan. Hal ini tidak sesuai dengan kecemasan yang ditampilkan saat pasien mengakui adanya persoalan pribadi yang mengganggu pikiran dan membuatnya tertekan. Dilakukan konseling untuk membantu pasien mengungkapkan kecemasan sehingga dapat meringankan beban pikirannya serta menganj ur-an pasien untuk mencari pertolongan dalam mengatasi masalah pribadinya.

Terlihat adanya perbaikan yang cukup signifikan pada kunjungan berikutnya, yaitu hanya terlihat 2 ulkus baru, namun masih tampak area kemerahan bekas ulkus yang menyebar di seluruh rongga mulutnya. Pasien mengaku sudah jauh lebih tenang setelah melakukan konseling dan mencari pe rtolo-ngan untuk mengatasi masalah pribadinya. Keluhan dalam rongga mulutnya sudah jauh berkurang. Dari kemajuan ini, dapat terlihat bahwa pada kasus 1, faktor stres psikologik berperan dalam peningkatan rekurensi dan keparahan lesi SAR.

Pada kasus 2, lesi SAR pertama kali muncul pada usia 28 tahun. Hal ini sesuai dengan karakteristik SAR minor, yaitu pemunculan pertama kali pada dekade $2-3^{3}$. Sariawan muncul tanpa didahului demam atau malaise, serta tidak didahului oleh lenting, sehingga disimpulkan bahwa lesi bukan akibat infeksi virus.

Pasien terlihat kurus sehingga diduga adanya defisiensi nutrisi. Kemudian ditanyakan pola makan pasien untuk menggali kemungkinan adanya defisiensi nutrisi. Ditemukan adanya asupan gizi yang kurang baik, dimana pasien makan 2 kali sehari dengan porsi kecil dan jarang makan sayur. Hasil pemeriksaan DPL memperlihatkan penurunan kadar $\mathrm{Hb}, \mathrm{Ht}$, MCV, dan MCH yang 
menandakan bahwa pasien menderita anemia mikrositik hipokrom. Hal ini dapat terjadi akibat defisiensi zat besi.

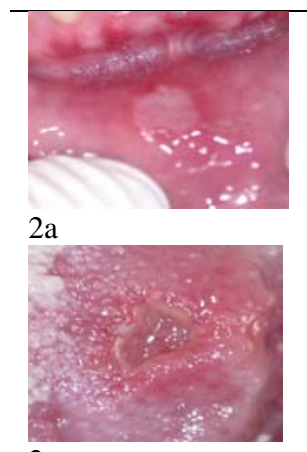

$2 \mathrm{e}$

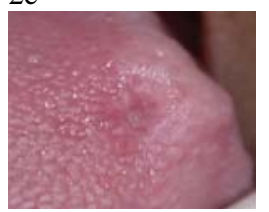

$2 \mathrm{i}$

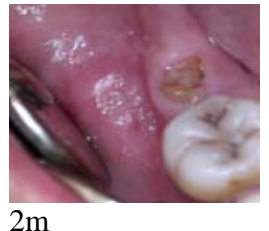

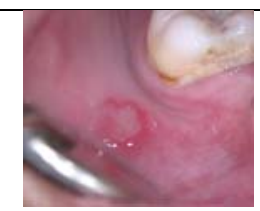

$2 b$

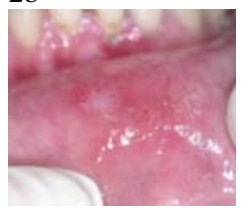

2f

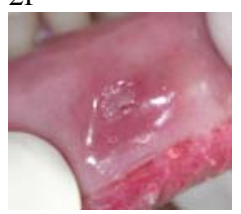

$2 \mathrm{j}$

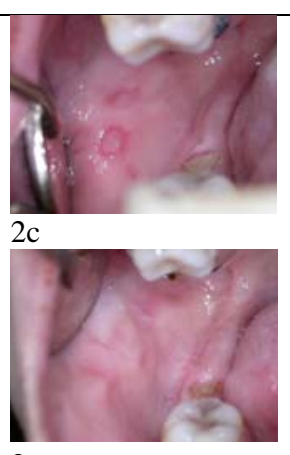

$2 g$

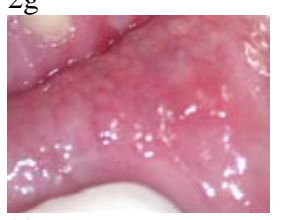

$2 \mathrm{k}$

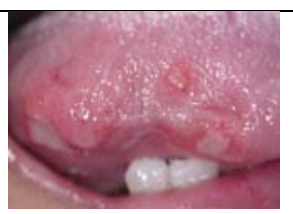

2d

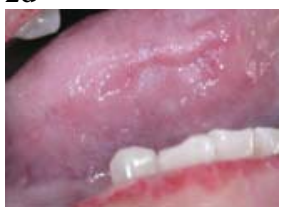

$2 \mathrm{~h}$

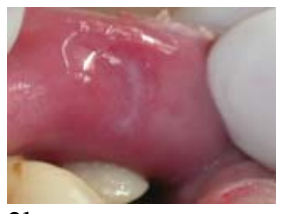

21

Gambar 2

Sariawan muncul sekitar 1 minggu sebelum menstruasi, sehingga diperkirakan perubahan hormonal berperan sebagai faktor predisposisi pada pasien ini. Pasien kemudian dirujuk ke poli Kebidanan untuk pemeriksaan hormonal, namun poli Kebidanan tidak melakukan pemeriksaan hormonal sesuai permintaan rujukan dan hanya melakukan pemeriksaan status ginekologis. Tidak diketah uinyastatus hormonal menyebabkan tidak dilakukan tindakan terhadap kondisi hormonal pasien.

Pada pemeriksaan intra oral sesuai panduan Natah SS, $\mathrm{dkk}^{3}, 4$ kriteria mayor terpenuhi yaitu beberapa buah ulkus dangkal berbentuk lonjong atau bulat berdiameter tidak lebih dari $1 \mathrm{~cm}$ dengan tepi regular dikelilingi halo eritem tanpa didahului lenting, dasar ulkus kuning-kelabu, rekurensi lebih dari 3 kali dalam 3 tahun terakhir dan tidak pernah pada lokasi yang sama, adanya rasa sakit yang dieksaserbasi oleh pergerakan pada daerah berulkus, serta semua ulkus sembuh spontan tanpa meninggalkan jaringan parut. Selain itu terpenuhi 6 kriteria minor, yaitu awal muncul sebelum usia 40 tahun, lokasi ulkus berpindah-pindah tetapi pada mukosa yang tidak berkeratin, durasi setiap pemunculan sekitar 7 hari, pemunculan dipicu perubahan hormonal, adanya defisiensi hematinik, pasien tidak merokok.

Eliminasi faktor-faktor predisposisi yang dilakukan adalah mengurangi jumlah koloni bakteri dalam rongga mulut untuk mencegah infeksisekunder serta memperce pat penyembuhan. Hal ini dilakukan dengan meningkatkan kebersihan rongga mulut melalui tindakan DHE, pemberian obat kumur povidon iodine $1 \%$ dan tetrasiklin, pembersihan karang gigi dan pencabutan gigi yang tidak dapat dirawat lagi, serta menghilangkan trauma lokal dalam rongga mulut. Koreksi defisiensi 
hematinik dilakukan dengan anjuran perubahan pola makan agar asupan gizi tercukupi, serta pemberian suplementasi multivitamin. Selain itu melakukan rujukan ke poli Kebidanan untuk mengevaluasi dan mengatasi perubahan hormonal yang mempengaruhi pemunculan lesi SAR., walaupun pada akhirnya hal tersebut tidak dilakukan oleh poli Kebidanan.

Rekurensi masih terjadi 1 kali dalam sebulan dengan jumlah ulkus 1 buah setiap pemunculan. Pasien merasa keparahannya berkurang yaitu tidak terganggunya pengunyahan dan bicara pasien akibat adanya ulkus tersebut.

Kondisi kasus 2 memburuk dengan adanya ulkus berjumlah 1-2 buah, hilang timbul tanpa henti selama satu bulan. Kemungkinan hal ini terjadi karena kelelahan dan stress psikologik. Sebab lain adalah sulitnya meminta pasien untuk patuh pada rencana perawatan. Hingga kunjungan keempat, pasien masih belum mau mencabut 5 sisa akar yang berdasarkan anamnesa men yeba-bkan iritasi pada mukosa bukal pasien selama ini.

Dilakukan re-evaluasi terhadap faktorfaktor predisposisi yang sebelumnya memang sudah terdeteksi. Pasien mengakui adanya persoalan pribadi dan kelelahan. Berdasarkan penilaian tingkat kecemasan menggunakan HRS-A, pasien berada pada tingkat kecemasan ringan. Dianjurkan untuk melakukan eliminasi faktor-faktor predisposisiseperti pada kunjungan sebelumnya.

Berdasarkan anamnesa 2 bulan kemudian diketahui terjadi penurunan frekuensi menjadi 1 kali dalam 2 bulan. Perbaikan ini menunjukkan bahwa eliminasi atau perbaikan faktor-faktor predisposisi dapat menurunkan frekuensi dan keparahan SAR.

Pada kasus 1, gambaran klinis SAR tampak lebih parah dengan frekuensi yang lebih sering bila dibandingkan dengan kasus 2 . Setelah dilakukan eliminasi faktor-faktor predisposisi, terlihat bahwa hasil pada kasus 1 tidaklah memuaskan, sedangkan hasil pada kasus 2 tampak cukup memuaskan walaupun faktor predisposisi lokal rongga mulut masih belum seluruhnya dieliminasi. Hal ini kemungkinan disebabkan adanya faktor genetik yang berperan besar pada kasus 1 . Hal ini sesuai dengan literatur yang menyatakan bahwa pasien dengan faktor genetik akan mempunyai gejala yang lebih parah ${ }^{3}$.

\section{Kesimpulan}

Menemukan dan melakukan eliminasi atau perbaikan seluruh faktor predisposisi dapat menurunkan frekuensi dan keparahan lesi SAR.

\section{Daftar Pustaka}

1. Porter S, Scully C. Aphthous Ulcers (recurrent). Clin Evid. 2004. 12.

2. Field EA, Allan RB. Review Article : Oral Ulceration - Aetiopathogenesis, clinical Diagnosis and Management in the Gastrointestinal clinic. Aliment Pharmacol Ther. 2003. 18 : 949-62

3. Natah SS, Konttinen YT, Enattah NS, Ashammakhi N, Sharkey KA, HayrinenImmonen R. Recurrent Aphthous Ulcers Today : A Review of the Growing Knowledge. Int $J$ Oral Maxillofac Surg. 2004; 33 : 221-34

4. Mirowski GW, Nebesio CL. Aphthous Stomatitis. http://www.emedicine.com/derm/topi c486.htm

5. Scully C. Aphthous Ulcers. http://www.emedici ne.com/ent/topic700.htm

6. Natah SS. Recurrent Aphthous Ulcers : Immuno-pathological aspects. Academic dissertation. Helsinski. 2001.

7. Greenberg MS, Glick M. Burket's Oral Medicine : Diagnosis and Treatment. $10^{\text {th }}$ ed. BC Decker Inc. Ontario. 2003. 63-65.

8. Melamed F. Aphthous Stomatitis. http://www. med.ucla.edu/modules/wfsection/article.php?arti cleid $=207$

9. Sedghizadeh PP, Shuler CF, Allen CM, Beck FM, Kalmar JR. Celiac Disease and Recurrent Aphthous Stomatitis : A Report and Review of the Literature. Oral surg Oral Med Oral Pathol Oral Radiol Endod. 2002; 94 : 474-78.

10. Katz J, Chaushu G, Peretz B. Recurrent Oral Ulcerations Associated with Recurrent Herpes Labialis-Two Distinct Entities?. Community Dent Oral Epidemiol. 2001; 29 : 260-3 
11. McBride DR. Management of Aphthous Ulcers. http://www.aafp.org/afp/20000701/149. html

12. Aphthous Ulcer (Canker Sore). http://www.max illofacialcenter.com/BondBook/mucosa/aphthou s.html

13. Ogura M, Yamamoto T, Morita M, Watanabe T. A Case-kontrol Study on Food Intake Patients with Recurrent Aphthous Stomatitis. Oral Surg Oral Med Oral Pathol Oral Radiol Endod. 2001. $91: 45-9$.

14. Soto-Araya M, Rojas-Alcayaga G, Esguep A. Association between Psychological Disorders and the Presence of Oral Lichen Planus, Burning Mouth Syndrome and Recurrent Aphthous Stomatitis. Med Oral. 2004. 9 : 1-7. 